\title{
Geo-electrical Investigation in Harir Plain Northeast of Erbil City
}

\author{
Fadhil A. Ghaib \\ Department of Geology \\ College of Sciences \\ Salahaddin University
}

(Received 17/12/2003 ; Accepted 28/7/2004)

\begin{abstract}
A total of 32 sites were investigated along three long cross-Alpine trend traverses in part of the Harir plain north of Iraq. Electrical resistivity method was applied. The main task of this study was to investigate the shallow structural and hydrogeological conditions by analyzing in detail the geo-electric sections, along the taken traverses. A set of NW-SE faults was distinguished. Their effect on the groundwater is discussed. A structural map is drawn for the area of study based on electrical data. Also a geologic cross section along one of the traverses was constructed.

\section{تحري جيوكهرائي فيسط حربرشمل

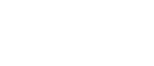

م التحري في بّ موقعاً عبر ثلاثة مقطعطويلة بالاتجه الالبي في جزءمنسهل حرير الكائن في شمل العراق بلستخدهمطريقة المقاومية الكهربائية. كلن الهذف الرئيسي من هذه الدرلسة هو التحري عن الأوضاع التركيبية الضحلة والميه الجوفية المتولجة وذك بتحليل تفصيلي للمقطع الجيوكهربائية التي قم لستتتلجها عبر المقطع الثلاثة. قم في الدرلسة لستنتاج مجموعة من الصدوع المتجهةشمل غرب -جنوب شرق في المطقة ونوقثت تأثيراتها. قم لسم خارطة تركيبية للمطقة ومتطعا جيولوجيا اعتمادا على البيانت الكهربائية.

\section{INTRODUCTION}

The studied area occupies about $30 \mathrm{~km}^{2}$. It is located in the Harir plain to the south of Harir town about 45km northeast of Erbil City in Iraqi Kurdistan Region (Fig. 1).

The area of Harir generally lacks adequate sources of surface water. Moreover, exploration of underground water in the area has some problems because of many geologic and structural reasons. There is consistent need for drilling water wells in this area. The geological reasons are that the limestone of the Bekhme Formation (The main aquifer in northern Iraq) has a very steep dip on the southwestern limb of the Harir Anticline. This situation is not favorable. The fissured limestone of the Pila Spi Formation (Another important aquifer) is very thin around the plain, a fact which makes it useless (Surdashy, 2003, University of Salahaddin, Pers. Com.) from the hydrogeological point of view.
\end{abstract}


Fadhil A. Ghaib

Fig. 1: Location map showing the geo-electric traverses. 
The resistivity method involves measuring the electrical resistivity of earth materials, by introducing an electrical current into the ground and monitoring the potential field developed by the current. In most earth materials, electricity is conducted electrolytically by the interstitial fluid. The resistivity is controlled mostly by porosity, water content and water quality than by the resistivities of the matrix (Ayer, 1989). The main target is identification of the horizontal and vertical variations in lithology, which might lead to more structural information about the subsurface.

\section{General geologic setting:}

The Harir plain is an elongated relatively low land. Geologically it covers an area that considered being a syncline bounded by the Harir Anticline from the northeast and the Mirawa Anticline from the southwest. Both Anticlines trend in the NW-SE direction. The two anticlines with the Shakrokr Anticline, which is located to the southeast of the study area, make up an en-echelon situation (Fig.2). The northwestern plunge of the Shakrokr Anticline descends beneath the Harir plain. It is not known how much this plunge extends beneath the plain. Parsons (1955) described the Harir and Shakrokr anticlines as two branches of one great compound structure. However it was found later that they are actually two separate anticlines, which is clear on Landsat imagery. The area is affected by a longitudinal fault running in the NW-SE direction (Numan, 2002). This fault had probably affected negatively upon the situation of the groundwater accumulation and movement.

The Harir area is located within the Folded Zone of Iraq according to the well-known (Dunnington, 1958) tectonic subdivision of the Iraqi territories.

The stratigraphic succession of the area could be briefed as follows:

The oldest rocks cropping out in the area belong to the Bekhme Formation (U.Cretaceous) (Fig.2). This formation makes up the core of both Harir and Shakrok anticlines and is composed of massive or layered dolomitic limestone. It is followed by the Shiranish Formation (U.Cretacious), which is composed of marl and marly limestone. The Shiranish Formation occupies the limbs of the Shakrokr Anticline. It is followed by the clastic rocks, which belong to the Kolosh and Gercus Formations (M.Paleocene and L.Eocene). They are composed of mudstones, shales, sandstones and marlstones. The Khurmala Limestone Formation (L. Eocene) is present as tongues within the upper part of the Kolosh Formation (Sissakian and Youkhana, 1978). It consists of well-bedded dolomitic or clayey limestone. The Pila Spi Limestone Formation (L.Eocene) is composed of dolomitic and chalky limestone. They are well bedded and fractured (Jassim and Sissakian, 1978 and Doski, 2002). The Fat'ha and Injana Formations follow the Pila Spi Formation. The first one is composed of alternating beds of mudstone, limestone, shale and sometimes-thin layers of evaporites. The second one is composed of alternating fractured beds of sandstone and mudstone, which are less competent than the former. 
Fig. 2: Geological map of Harir area. (From FAO coordination of Northern Iraq, Erbil, 2001).

\section{Fieldwork:}

A basic rule in resistivity prospecting states that the subsurface layers should be as gentle as possible to avoid errors (Keary and Brooks, 1991). However by choosing the electrode spread in the strike direction these errors could be decreased and the thickness of units will represent the drilling thickness.

A total of 32 Vertical Electrical Soundings (VES) were executed during September 2002 along three traverses that trend in NE-SW direction (i.e. almost perpendicular to Alpine-trend of the High Folds Zone of Iraq) (Fig. 1). Traverse (A) extends for about $6.5 \mathrm{~km}$ and includes 13 VES points. Traverse (B) extends for about $6 \mathrm{~km}$ including 10 VES points while traverse (C) extends for about $8.5 \mathrm{~km}$ and includes 9 VES points. The distance between successive measurement points was variable ranging from 400 to $2000 \mathrm{~m}$ depending upon topography and surface geological indications. The maximum total spread of electrodes (AB distance) at each point was $1400 \mathrm{~m}$ using the Schlumberger configuration. The distance between traverses (A) and (B) was 2-3 km while between traverse (B) and (C) was 1-1.5 km. The SAS 4000 Terrameter (ABEM) was applied in 
resistivity measurements while the GPS (model Garmin) was used in positioning and elevation measurements of the points of investigation.

\section{Interpretation of resistivity data:}

The VES curve at each point had been interpreted individually using the ipi2win Russian commercial program (Geo-scan-M, 2001, Moscow State University). True resistivities and depth of horizons for the interpreted sounding curves are given in

(Table 1). After that a geo-electric section was manually constructed for each traverse (Figs. 3, 4 and 5). Clear outcrops of Bekhme, Pila Spi and Khormala formations were of great importance in constructing these sections.

Table 1: True resistivity values of the interpreted sounding curves.

\begin{tabular}{|c|c|c|c|c|c|c|c|c|c|c|c|c|}
\hline VES & $\rho 1$ & H1 & $\rho 2$ & H2 & $\rho 3$ & H3 & $\rho 4$ & H4 & $\rho 5$ & H5 & 66 & H6 \\
\hline $1 \mathrm{~A}$ & 1220 & 60 & 600 & 160 & 240 & & & & & & & \\
\hline $2 \mathrm{~A}$ & 330 & 26 & 420 & 85 & 400 & 386 & 86 & & & & & \\
\hline $3 \mathrm{~A}$ & 15 & 20 & 65 & 126 & 320 & 306 & 420 & 420. & Inf. & & & \\
\hline $4 \mathrm{~A}$ & 9 & 18 & 22 & 180 & 10 & 340 & 42 & 425 & 305 & & & \\
\hline $5 \mathrm{~A}$ & 10 & 35 & 8 & 163 & 95 & 195 & 55 & 293 & 16 & 475 & 300 & \\
\hline $6 \mathrm{~A}$ & 95 & 38 & 20 & 141 & 8 & 192 & 48 & 341 & 26 & & & \\
\hline $7 \mathrm{~A}$ & 12 & 23 & 21 & 83 & 120 & 206 & 80 & & & & & \\
\hline $8 \mathrm{~A}$ & 13 & 72 & 11 & 193 & 60 & & & & & & & \\
\hline $9 \mathrm{~A}$ & 9 & 59 & 27 & 241 & 55 & & & & & & & \\
\hline $10 \mathrm{~A}$ & 11 & 24 & 38 & 109 & 25 & & & & & & & \\
\hline $11 \mathrm{~A}$ & 14 & 78 & 26 & & & & & & & & & \\
\hline $12 \mathrm{~A}$ & 12 & 37 & 23 & 123 & 15 & 194 & 70 & 281 & 34 & & & \\
\hline $13 \mathrm{~A}$ & 9 & 15 & 90 & 32 & 14 & 82 & 49 & 131 & 28 & & & \\
\hline $1 \mathrm{~B}$ & 37 & 53 & 370 & 132 & 85 & & & & & & & \\
\hline $2 B$ & 9 & 49 & 15 & 189 & 5 & 306 & 22 & & & & & \\
\hline $3 B$ & 26 & 61 & 44 & 178 & 145 & 256 & 10 & & & & & \\
\hline $4 \mathrm{~B}$ & 27 & 59 & 48 & 139 & 24 & 337 & 43 & & & & & \\
\hline B5 & 46 & 21 & 11 & 136 & 85 & & & & & & & \\
\hline $6 \mathrm{~B}$ & 35 & 61 & 17 & 91 & 21 & 181 & 58 & & & & & \\
\hline $7 B$ & 36 & 69 & 85 & 96 & 16 & 172 & 49 & & & & & \\
\hline $8 B$ & 20 & 92 & 15 & 408 & 60 & & & & & & & \\
\hline $9 B$ & 18 & 450 & 70 & & & & & & & & & \\
\hline 10B & 15 & 105 & 7 & 160 & 60 & & & & & & & \\
\hline $1 \mathrm{C}$ & 120 & 21 & 20 & 52 & 290 & 198 & 120 & & & & & \\
\hline $2 \mathrm{C}$ & 65 & 32 & 54 & 153 & 25 & & & & & & & \\
\hline $3 \mathrm{C}$ & 10 & 22 & 39 & 91 & 22 & 120 & 165 & & & & & \\
\hline $4 \mathrm{C}$ & 22 & 42 & 105 & 180 & 67 & 231 & 140 & & & & & \\
\hline $5 \mathrm{C}$ & 10 & 20 & 20 & 84 & 75 & 480 & 25 & & & & & \\
\hline $6 \mathrm{C}$ & 11 & 40 & 36 & 103 & 64 & & & & & & & \\
\hline $7 \mathrm{C}$ & 20 & 18 & 12 & 51 & 52 & & & & & & & \\
\hline $8 \mathrm{C}$ & 25 & 15 & 56 & 49 & 65 & 127 & 15 & & & & & \\
\hline $9 \mathrm{C}$ & 19 & 1510 & 120 & 80 & & & & & & & & \\
\hline
\end{tabular}


Fadhil A. Ghaib

Fig. 3: Geo-electric section along trarese A. 
Geo-electrical Investigation In Harir Plain ...

Fig. 4: Geo-electric section along trarese B. 
Fadhil A. Ghaib

Fig. 5: Geo-electric section along trarese C. 


\section{Geo-electric sections:}

A geological section may show a series of lithologically defined interfaces, which do not necessarily coincide with boundaries identified electrically. A geo-electric unit is characterized by two basic parameters; the layer resistivity and the layer thickness. In constructing the geo-electric sections of Harir area, dips and locations of the present outcrops relative to the executed traverse were used as guides to extrapolate the boundaries between different electrical horizons.

As expected, a lot of horizontal and inclined horizons are defined in the three geo-electrical sections (Figs 3, 4 and 5). Horizons that are located at the middle part of the three sections are almost horizontal while those near the southwestern Harir Anticline's limb are inclined towards southwest following by definition the bedding planes. Horizons on the other side of the sections are inclining towards northeast.

Electrical horizons are in general features reflecting similar subsurface structures. Resistivity values begin from hundreds and thousand of ohm.ms. in the northeastern parts reflecting dolomitic limestone and limestones of Cretaceous rocks (Bekhme and Shiranish Formations) to tens of ohm.ms. or even less in the southwestern parts of the three sections indicating the clayey clastics (Injana, Gercus and Kolosh Formations). Discontinuities in resistivitiy values are dominant laterally.

\section{Resistivities of rock formations in Harir area:}

It should be emphasized that the observed resistivity value does not measure the true resistivity of any particular volume of earth unless the material is homogeneous. For nearly all earth materials an essential theoretical fact to keep in mind is that resistivity decreases with increasing water content and with increasing water salinity. This principle leads to the conclusion that non-porous materials will exhibit relatively high resistivity values since the water content will necessarily be little unless in case of fissuring and fracturing. This category includes limestones of Bekhme, Shiranish, Pila Spi and Fat'ha formations. Other high resistivity materials include those, which are porous but contain little or no water such as the sandsone of Kolosh, Gercus and Injana formations. The claystone (in Gercus and Kolosh formations) on the other hand exhibit the lower resistivity values among rocks because the type of conducting currents is electronically rather than electrolytically. By the extrapolation of the present outcrops based on the geo-electric horizons, resistivity values are concluded for the rock units present in the studied area (Table 2).

Table 2: Resistivity values of rock formations in Harir area.

\begin{tabular}{|c|c|}
\hline Formation name & Range of resistivity (ohm.m.) \\
\hline Bekhme & $240->1550$ \\
\hline Shiranish & $37-420$ \\
\hline Kolosh + Gercus & $5-80$ \\
\hline Pila Spi & $65-145$ \\
\hline Fat'ha & $10-105$ \\
\hline
\end{tabular}

It is observed that the resistivity values in almost all cases increase with depth possibly due to compaction.

\section{Water table:}


The determination of the depth to water table is generally a difficult problem and it is based on a comprehensive understanding of field conditions especially the structural, geomorphological and stratigraphic set-up in any area of investigation.

Wherever the water table is overlain and underlain by several layers of different resistivities, its detection on a sounding curve may be virtually impossible (Zohdy, 1969). Unfortunately this is the case in the studied area. Under favorable conditions the water table can be detected on the sounding curve as a conductive layer.

The author suffered a lot to define roughly the water table in some parts of the traverses. For this purpose resistivity values for aquifers from vertical electrical sounding curves that were carried out in adjacent to some water wells of known depth of water were collected (Table 3). These wells are located in Harir basin (Batas well, north of Harir town) and Mirawa basin southwest of Mirawa Anticline as well as in Erbil basin (Ghaib, 2003 and Ghaib and Aziz 2003). These values in addition to the water depth in a water-well situated near the beginning of traverse (B) (about $1 \mathrm{~km}$ to the south of the traverse) were used as bases in order to estimate the depth of water table in some situations (Figs. 4 and 5). The water level is situated at depths ranging from 40 to $60 \mathrm{~m}$ below surface in the northeastern parts of the area while it has an average depth of about 80 in the southwestern parts.

Table 3: Resistivity values of some saturated rocks.

(Ghaib, 2002 and Ghaib and Aziz 2003)

\begin{tabular}{|c|c|}
\hline Saturated rock unit & Resistivity (ohm.m) \\
\hline Sandstone & $70-300$ \\
\hline Mixture of clay, silt, sand and gravel & $15-45$ \\
\hline Fissured limestone & $20-150$ \\
\hline Karstic dolomitic limestone & $200-700$ \\
\hline
\end{tabular}

\section{Structural significance and discussion:}

The area under investigation covers a small part of the Harir plain, which is located on the envisaged Harir Syncline. The area is bounded from the northeast by the southwestern limb of the Harir Anticline, which plays an important role in the location of aquifer in the area. The high dips on this limb preclude the presence of any sizeable aquifer near of the Harir mountain front.

The method of resistivity as applied in this study has shown that a number of subsurface faults (indicated as discontinuities in the geo-electric sections) exist in the Harir Syncline. Because only NE-SW traverses were taken the inferred faults are considered to be longitudinal running parallel to the axis of Harir Anticline. A structural map is drawn for the area of study based on the present data (Fig. 6). The inferred faults are in agreement with two main sets of faults estimated by Al-Dawoody (2004) in a recent gravity study. Moreover a cross section along the traverse (B) was also constructed by the aid of the geo-electrical section and surface geological features (Fig. 7).

The effect of these faults on water prospects and aquifer localization may vary from positive to derogatory depending on whether they help percolate water to inaccessible depths or whether they help confine an aquifer by bringing it into contact with impervious rocks. 
Fig. 6: Structural map as inferred from electric data.

Taking in mind the effect of faults that are defined, the water table is still remaining a matter of argument. Al-Nabawy (2002) has constructed a simple flow net for the groundwater using the limited data of the widely scattered wells in Harir basin. She concluded that along the distance of the traverses of the present study (from northeast to southwest) the water elevation above sea level fluctuates in the order of $200 \mathrm{~m}$ per $4 \mathrm{~km}$ distance (i.e. about $65 \mathrm{~m}$ in terms of depth). This value of fluctuation is not found in areas of simple geology such as Erbil basin and it is mostly attributed to the effect of structure.

In northern Iraq it is well known that the topography is quite affected by the role of the subsurface structure in dictating the geomorphologic patterns and hence the catchment areas. It is also well known that the aquifers are controlled by climate, lithology, permeability, porosity, geomorphology and structural geology. The structural framework of the studied area is most effective factor. In the High-Folded Zones of Iraq the structures underneath brood synclines such as the present one are never horizontal and simple (Ghaib, 2001). Instead, faulting or strata of high amounts of dip mostly affect them. Limbs of high dips (more than 30 degrees which is generally the case in this study) are not favorable for accessible aquifers since water percolates and is lost down dip to great depths (Numan, 2000). 
Fadhil A. Ghaib

Fig. 7: Estimated geologic section along traverse B. CONCLUSION 
The interpretation results of the three relatively long traverses indicated that the Harir plain are subjected to many longitudinal reverse faults parallel to the main structure. This structural framework in addition to the steep southwestern limb of Harir Anticline creates unfavorable conditions for storing groundwater. Roughly estimated depth of water indicated that it is deeper in the southwestern parts of Harir plain than in the northeastern parts.

\section{REFERENCES}

Al-Dawoody, A.N., 2004. Gravity study in the Harir area/ Iraqi Kurdistan Region, Unp. M.Sc. Thesis/ Salahaddin University, Erbil, Iraq, 90p.

Al-Nabawi, A.K., 2002. Hydrogeology and Hydrochemistry of Harir basin- Iraqi Kurdistan, Unp. M.Sc. Thesis, Salahaddin Univ., Erbil, 154p.

Al-Shaikh, Z.D., Salih, H.A. and Abdo, H.F., 1975. Contribution to the geology of Shaqlawa-Harir area. Irq. J. Geo. Soc., Special issue, pp. 55-67.

Ayer, J.F., 1989. Conjunctive use of geophysical and geological data in the study of an alluvial aquifer, Groundwater, V.27, N.5, pp. 625-632.

Dosky, J. A. H., 2002. Structural study along selected structural sections across Safin Anticline. Unp. M.Sc. Thesis, Salahaddin University, Erbil, 164p.

Dunnington, H. V., 1958. Generation, Migration, Accumulation and Dissipation of Oil in Northern Iraq, AAPG., Special issue, pp. 1194-1251.

Ghaib, F. A., 2001. Geophysical study of the Erbil and Aqra Plains and their geological implications, Unp. Ph.D. Thesis, Salahaddin University, Erbil, 195p.

Ghaib, F. A. and Aziz B. K., 2002. A combination of electrical and gravity measurements for groundwater prospection in parts of Erbil City, J. of Duhok Univ.,Vol.6, No.1, pp. 105-111.

Ghaib, F. A., 2003. Geophysical survey for groundwater in some selected basins of Erbil Governorate, internal report, FAO representation in Iraq, Erbil sub-office, 69p.

Jassim, S.Z. and Sissakian, V., 1978. Field guide to the geology of Salahaddin-Shaqlawa area, NE-Iraq, Geol. Soc. Iraq, Geol. Cong. Baghdad, pp. 25-33.

Keary, B. and Brooks, M., 1991. An introduction to geophysical exploration, Blackwell scientific publications, 254p.

Numan, N. M. and Al-Azzawi, N.K.B., 1993. Structural and geotectonic interpretation of vergence directions of anticlines in the Foreland Folds of Iraq, Abhath-Yarmouk, Jordan, Vol.2, No. 2, pp. 57-73.

Numan, N. M., 2002. Structural and tectonic investigation in northern Iraq. FAO, Internal Report, Erbil, 81p.

Parsons, R. M., 1955. Ground water resources of Iraq, V9, Hydrologic aspects of selected areas, Development board, Ministry of Development, Iraq, 142P.

Sissakian V. and Youkhana, R., 1978. Report on regional mapping of Erbil-Shaqlawa-Quwaisinjaq-Raidar area. D. G. of Geological Survey and Miner. Invest. Baghdad, internal report, 112p.

Zohdy,A.A.R., 1969. The use of Schlumberger and equatorial soundings in groundwater investigations near El Paso, Texas, Geophysics 34, pp. 713-728. 